JRSSEM 2021, Vol. 01, No. $4,333-339$

E-ISSN: 2807 - 6311, P-ISSN: 2807 - 6494

\title{
DIGITAL LIBRARY INFORMATION SYSTEM AT BREBES BOARDING SGHOOL VOCATIONAL HIGH SGHOOL
}

\author{
Aji Wicaksono* \\ Informatics Engineering Department, Baja Tegal Polytechnic, Indonesia \\ e-mail: ajibijaksana@gmail.com \\ *Correspondence: ajibijaksana@gmail.com
}

Submitted: 1 November 2021, Revised: 13 November 2021, Accepted: 14 November 2021

\begin{abstract}
In education, information technology is indispensable for students and teachers to gain broad knowledge. Students will look for additional information other than what the teacher teaches, all of which can be obtained from the library. The library is one of the facilities owned by the Brebes Boarding School Vocational School. A librarian and two administrative staff handle the library. Administrative tasks are very diverse, quite a lot. So far, the administration processes member data input, book data input, loan return input and makes annual, monthly, daily reports using computerization. Is it only with computerization in the library? Then what if students want to know information about what book collections are available without having to come to the library or not. This research aims to design a digital library application that students and teachers can access via the internet. This research uses a quantitative descriptive method. In making a digital library information system, the design method goes through several stages such as problem analysis, review studies, system design, display design, testing, and evaluation. The existence of this digital library information system can facilitate information about what book collections are available without having to come to the library.
\end{abstract}

Keywords: information system, digital library, DFD, dreamweaver CS4, SQL Server 2008. 


\section{INTRODUCTION}

Today's advances in technology and information have developed very rapidly and continue to grow to create engineering objects that can help humans (Lee et al., 2018). The development of computer technology has an essential role in life. The application of information technology provides convenience for agencies or institutions, as stated by (A. Siregar, 2020). Information Technology can provide added value in the learning process (Putra, 2017). In education, information technology is indispensable for students and teachers to acquire broad knowledge (Riwayadi, 2013). Students will seek additional information other than what the teacher teaches, all of which can be obtained from the library. The library is one of the facilities owned by the Brebes Islamic Boarding School. Digital library not from its kind of library, but a development in the library service system (Irfiani \& Indriyani, 2013). The library is handled by a librarian and two people in the administration. Administrative tasks are pretty diverse (Ferreira et al., 2010). So far, the administration has processed member data input, inputting book data, inputting borrowing and returning data, and making daily and annual, monthly reports using a computer (Hendrianto, 2013) . But is it only with the computerized system in the library, then what if students want to know information without having to come to the library and librarian who wish to convey information to students without students not having to go to a place such as reports for students who have not returned books and supplies books, etc.? For this reason, it is necessary to design a digital library information system that students can access via the internet. In making this digital library information system, we will only discuss user data, member data, digital book data, and information in the library.

The goal to be achieved in this research is that it is easier for students to obtain library information without coming to the library. Pesantren Vocational School and assist the librarian, and administrative tasks manage the library. In working on this digital information system using research methods and design methods, data flow diagrams (DFD) with the Dreamweaver CS4 SQL Server 2008 application for database design.

\section{METHODS}

This research uses a quantitative descriptive method (Creswell \& Creswell, 2017) with a case study at the Brebes Vocational High School, and the development of this research uses the flow as shown in Figure 1 below:

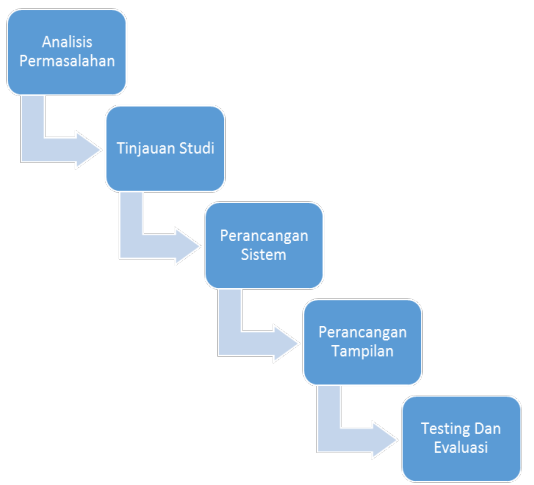

Figure 1. Research Stages

Figure 1 discusses the stages of the research, consisting of the stages of problem analysis, review of studies, system design, display, testing, and evaluation. The analysis stage consists of the problem stage of the study review carried out by reviewing previous researchers' research, at 
the design stage with DFD modeling, which uses DFD CD DFD level 1 and DFD level 0.

SQL Server 2008 is one of the breakthroughs in the field of Microsoft databases (Nugroho, 2008).

This creates a confident attitude from users towards the library. The library must know this user perception for essential material evaluation of the facilities and services carried out (Anwar \& Hasibuan, 2013). Currently, the library user community wants the library to be the correct information, right user, and right now. This means that libraries are required to provide accurate information services to users in a timely and fast manner (Pebrianto, 2011).

Evaluation of IT needs as an effort to prepare the library in optimizing the application of IT in the library information system. So that the application of IT is not just prestige but a strategy. This can be done well if the library can present and take advantage of the development of information technology in library processing (B. G. Siregar, 2017).

The library information system is a device used in library processing that aims to assist the library administration system (Mujilahwati \& Muhtadin, 2014).

Electronic libraries use the internet as a widely used medium to find information to be more effective (Firdausy \& Yudhana, 2008).

\section{RESULTS AND DISCUSSION}

\section{Business Process}

Brebes boarding school vocational school is one of the schools in the Brebes area with 2 study programs (TKJ) Computer
Network Engineering and (TKBB). Concrete Construction Engineering DF is a tool to describe data flow from a DFD component system consisting of storage (data store), Entity (terminator) process, and data flow. For more details, see DFD CD Below:

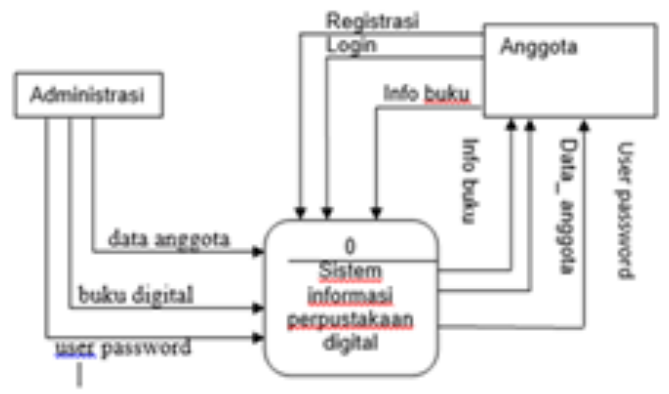

Figure 2. Library Context Diagram

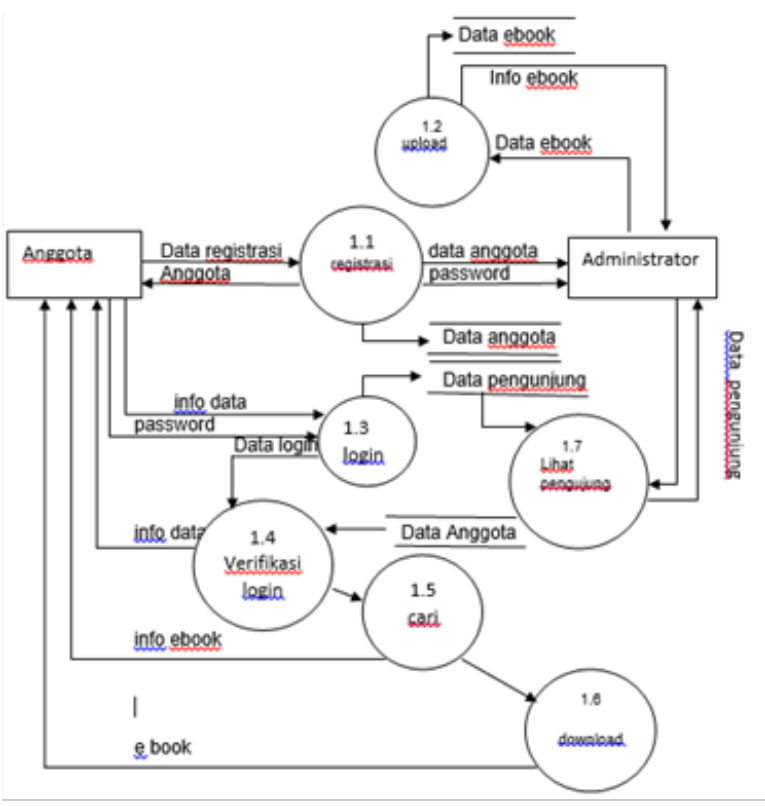

Figure 3. DFD LEVEL 0 Digital Library Information System 


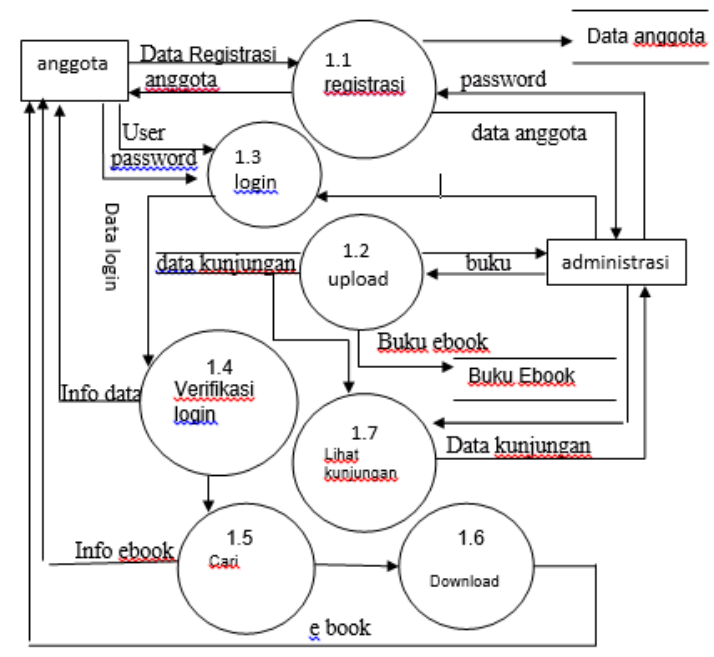

Figure 4. DFD LEVEL 1 Digital Library Information System

\section{System Design}

The system design stage is planning to build and configure software and hardware components to produce a sound system. The system analyst proposed by the researcher is explained in the form of a diagram. (Burch et al., n.d.)

Flowchart Systems is a diagram that shows the overall workflow of the system. This diagram describes the sequence of procedures that exist in the system. The system flow chart shows what the system does. (Mujilahwati \& Muhtadin, 2014)

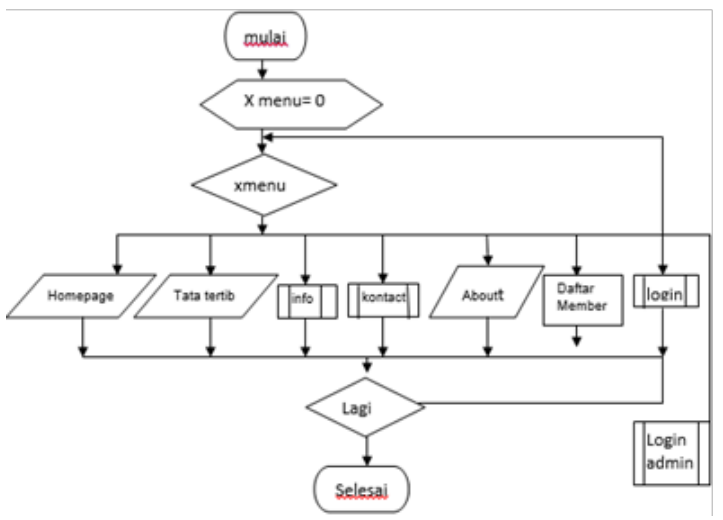

Figure 5. Flowchart of Main Menu Page

Figure 5 above illustrates the flowchart of the main menu page in the design of a digital library information system that contains the home page menu, rules, info, contact, about, member list, and log in. In Figure 6 below, there is a flowchart of the info menu. We can find out information about the book collection on the info menu.

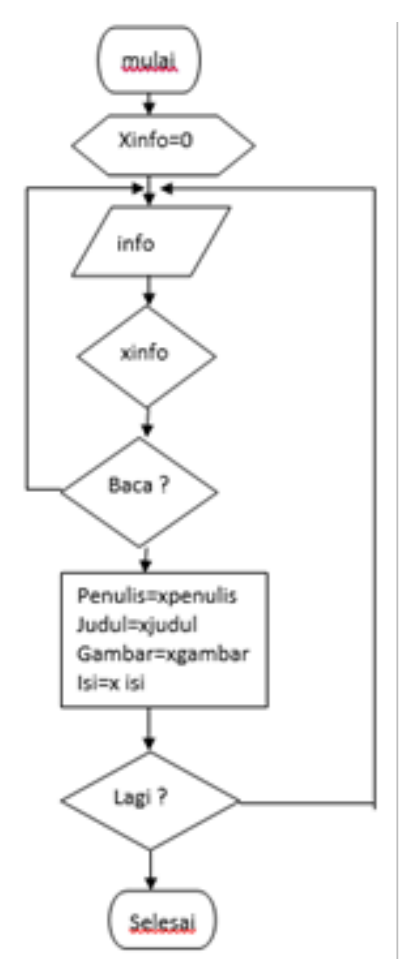

Figure 6. Flowchart Menu Info

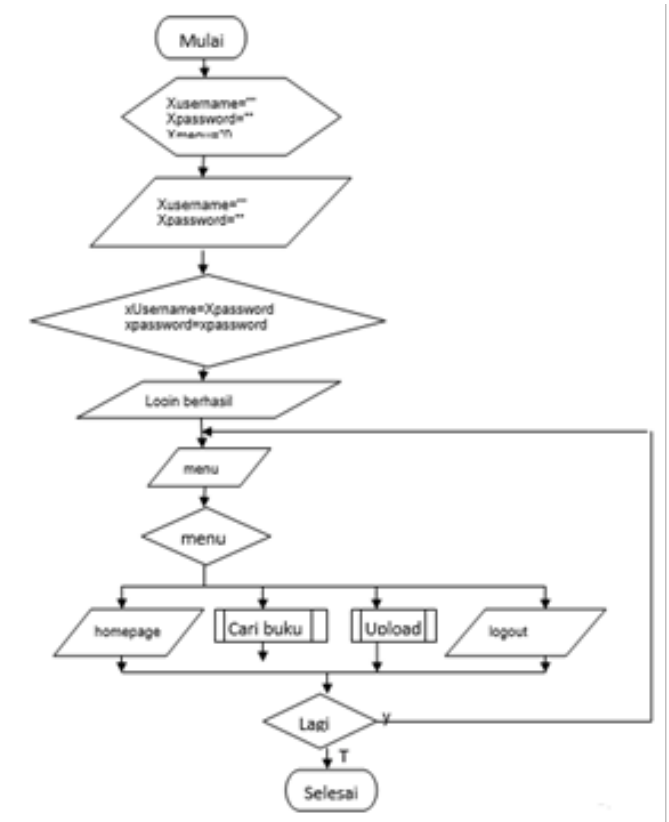

Figure 7. Member List Flowchart 
Figure 7 above illustrates the flowchart of the member list menu. On this menu, we can register as library members without coming directly to the library. Figure 8 below shows the flowchart of the member login menu. We can log in on this menu if we are already registered as library members.

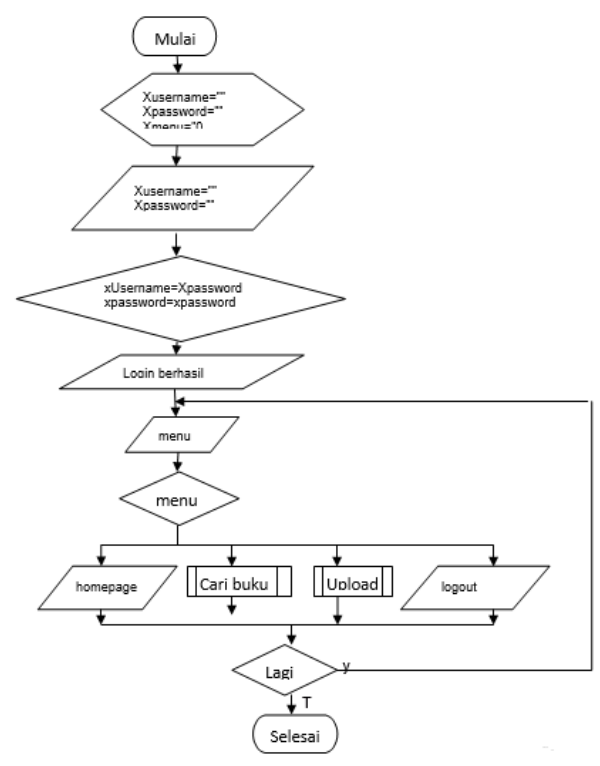

Figure 8. Member Login Flowchart

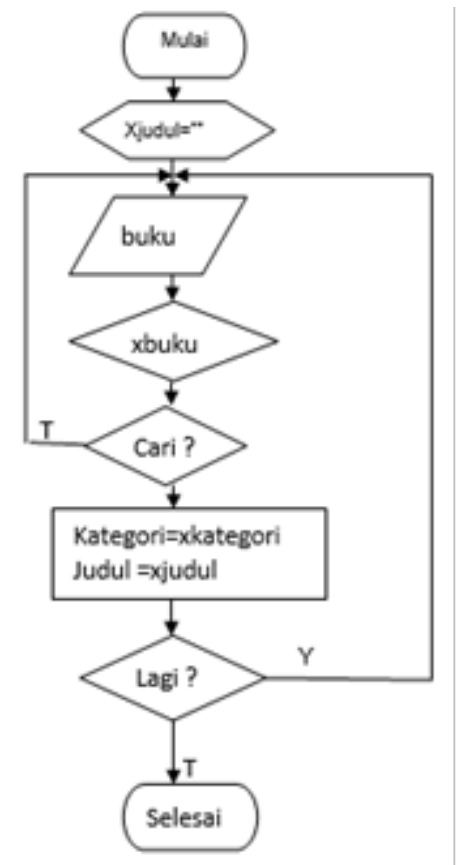

Figure 9 above is a book search flowchart. On this menu, we can search for a collection of books in the library. Figure 10 below illustrates the flowchart of the proposed library system.

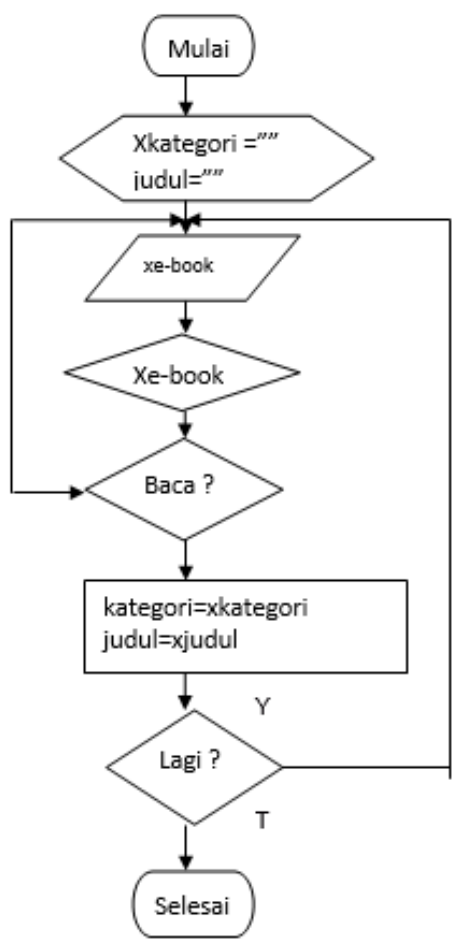

Figure 10. Proposed Flowchart

\section{Display Design}

The display design in Figure 11 aims to provide an overview of the display design of the application that it will create.

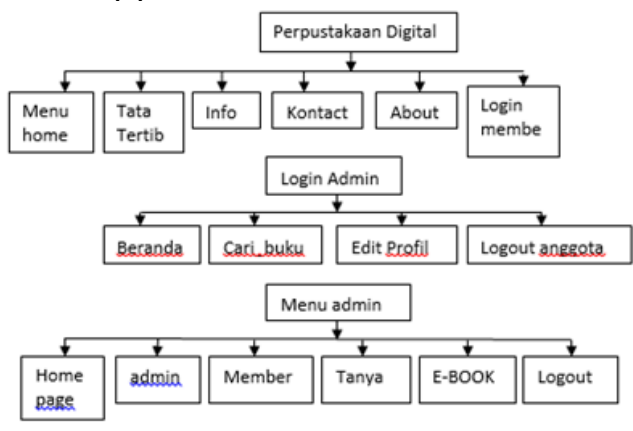

Figure 11. Display Structure

1. Login View

The login display is used for admins to enter the main menu to manage the 
digital library information system.

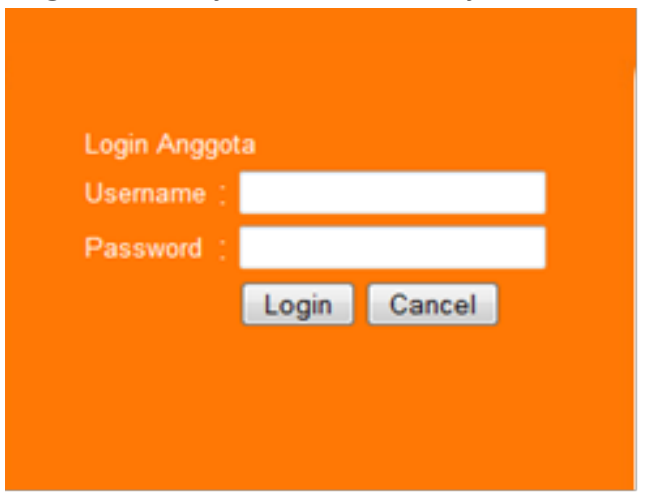

Figure 12. Login View

2. b. Main Menu Display

The main menu displays to manage or display all forms contained in the digital library information system.

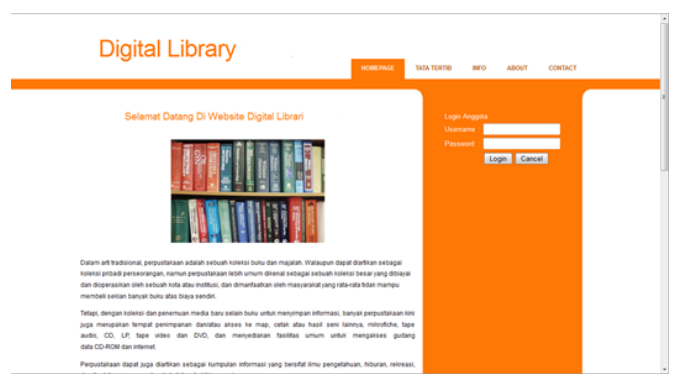

Figure 13. Main Menu Display

3. Menu Display Search Books

In the search menu, the function searches for books in the Brebes Boarding School Vocational School library.

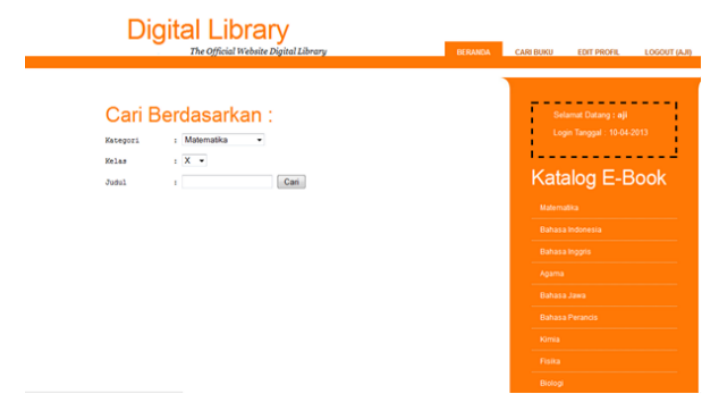

Figure 14. Display of the Search Book Menu

\section{CONCLUSIONS}

Based on the results of the preparation and observations made at the Brebes Boarding School Vocational School on the creation of a digital library information system, the authors can draw the following conclusions, in making this application, it is hoped that it can help library administration tasks to provide information for teacher students through the internet network. Make it easier for students and teachers to get library information without coming directly to the library. This Library Information System has a menu of book collections in the library so that it can facilitate data collection of book collections for library administration and make it easier to find books for students and teachers

\section{REFERENCES}

Anwar, S., \& Hasibuan, M. F. (2013). Penerapan Aplikasi Peminjaman Dan Pengembalian Buku Pada Perpustakaan Madrasah Aliyah Al-Ahliyah Kota Baru. Simnasiptek 2013, 1(1), 38-42.

Burch, J., Grudnitski, G., \& Scott, G. M. (n.d.). Perancangan Sistem Secara Umum.

Creswell, J. W., \& Creswell, J. D. (2017). Research design: Qualitative, quantitative, and mixed methods approach. Sage publications.

Ferreira, E. J., Erasmus, A. W., \& Groenewald, D. (2010). Administrative management. Juta and Company Ltd.

Firdausy, K., \& Yudhana, A. (2008). Sistem Informasi Perpustakaan berbasis Web dengan PHP dan MySQL. TELKOMNIKA, 
6(2), 109.

Hendrianto, D. E. (2013). Pembuatan sistem informasi perpustakaan berbasis website pada sekolah menegah pertama negeri 1 donorojo kabupaten pacitan. IJNS-Indonesian Journal on Networking and Security, 2(4).

Irfiani, E., \& Indriyani, F. (2013). Sistem Informasi Perpustakaan Digital Berbasis Web Pada SMP Citra Negara Depok. Simnasiptek 2013, 1(1), 91-97.

Lee, M., Yun, J. J., Pyka, A., Won, D., Kodama, F., Schiuma, G., Park, H., Jeon, J., Park, K., \& Jung, K. (2018). How to respond to the fourth industrial revolution or the second information technology revolution? Dynamic new combinations between technology, market, and society through open innovation. Journal of Open Innovation: Technology, Market, and Complexity, 4(3), 21. https://doi.org/10.3390/joitmc4030021

Mujilahwati, S., \& Muhtadin, S. (2014). Sistem Manajemen Perpustakaan (Online) Pada SMP "Empat Lima" 2 Kedungpring Lamongan. Jawa Timur.

Nugroho, A. (2008). Belajar Sendiri Mengimplementasikan SQL Server 2008. Elex Media Komputindo.

Pebrianto, S. (2011). Pembangunan Sistem Informasi Perpustakaan Pada Perpustakaan Umum Kabupaten Pacitan. Speed-Sentra Penelitian Engineering Dan Edukasi, 2(2). http://dx.doi.org/10.3112/speed.v2i2.1 255

Putra, C. A. (2017). Pemanfaatan Teknologi Gadget Sebagai Media Pembelajaran. Bitnet: Jurnal Pendidikan Teknologi Informasi, 2(2), 1-10. https://doi.org/10.33084/bitnet.v2i2.75

2

Riwayadi, P. (2013). Pemanfaatan Perkembangan Teknologi Informasi Dan Komunikasi Untuk Kemajuan Pendidikan Di Indonesia. Available at PLS-UM Database.

Siregar, A. (2020). Perancangan Sistem Informasi Penggajian Berbasis Web Pada CV. Alona Jaya. Jurnal Indonesia Sosial Teknologi, 1(4), 253-264. https://doi.org/10.36418/jist.v1i4.40

Siregar, B. G. (2017). Implementasi manajemen perpustakaan berbasis teknologi untuk percepatan pelayanan. Al-Kuttab: Jurnal Perpustakaan Dan Informasi, 4(1), 16-32. https://doi.org/10.24952/ktb.v4i1.619

(c) () (ㅇ $₫ 2021$ by the authors. Submitted for EY SA possible open access publication under the terms and conditions of the Creative Commons Attribution (CC BY SA) license (https://creativecommons.org/licenses/by-sa/4.0/). 